\title{
INOVASI PENDIDIKAN AKHLAK BERBASIS MANAJEMEN QOLBU
}

\author{
Ahmad Manshur ${ }^{1}$ \\ Institut Agama Islam Sunan Giri Bojonegoro \\ ahmadmanshur@gmail.com
}

\begin{abstract}
Abstrak
This paper discuse about moral innovation education based qolbu management, the occurrence of acts violence lately is a phenomenon that we often witness. In fact it almost always adorns mass media information. An example is the fight between students, rape, arson, murder, slaughter, and other anarchist acts. That is one of the phenomena of moral crisis which is now affecting our nation. Besides that, there are still many other moral crises, such as drinking, drug abuse, bribery and so on. The multidimensional crisis that befell this nation, one of the causes - and perhaps this is the most important cause - is due to a moral or moral crisis. The moral crisis occurs because most people no longer want to heed religious guidance. The Qolbu Management-Based Moral Education Innovation is a new idea or method offered by the author to be used in implementing moral education. And it is hoped that this new idea or method can improve the quality of moral education which is felt to be declining today. The way to do qolbu management-based moral education innovation is to always adorn oneself from praiseworthy qualities, after cleansing it from despicable traits, removing love for the world and eliminating all sorrow, grief and worries.
\end{abstract}

Keyword: Qolbu Management, Morality, Innovation.

\section{A. PENDAhUluan}

Terjadinya aksi dan tindak kekerasan (violence) akhir-akhir ini merupakan fenomena yang seringkah kita saksikan. Bahkan hal itu hampir selalu menghiasi informasi media masa. Sebagai contoh adalah, terjadinya tawuran antar pelajar, pemerkosaan, pembakaran gedung, pembunuhan, pembantaian, dan tindak anarkis yang lain. Itulah salah satu fenomena krisis akhlak yang kini tengah menimpa bangsa kita. Disamping itu, masih banyak krisis akhlak yang lain, seperti mabuk-mabukkan, penyalahgunaan narkotika, suap dan lain sebagainya. Krisis multi dimensional yang menimpa bangsa ini, salah satu penyebabnya dan boleh jadi ini merupakan sebab yang paling utama- adalah karena terjadinya krisis moral atau akhlak. Krisis moral terjadi karena sebagian besar orang tidak mau lagi

\footnotetext{
${ }^{1}$ Dosen Institut Agama Islam Sunan Giri Bojonegoro
} 
mengindahkan tuntunan agama, yang secara normative mengajarkan kepada pemeluknya untuk berbuat baik, meninggalkan perbuatan-perbuatan maksiat dan munkarat. ${ }^{2}$

Islam memuji akhlak yang baik, menyerukan kaum muslimin untuk membinanya, dan mengembangkannya di hati mereka. Islam menegaskan bahwa bukti keislaman ialah akhlak yang baik. Selain itu puncak derajat kemanusiaan seseorang dinilai dari kualitas akhlaknya. Maka tak heran jika kualitas keimananpun di ukur dari akhlak. Seluas apapun kadar keilmuan seseorang tentang Islam, sehebat apapun dirinya ketika melakukan ibadah, atau sekencang apapun pengaduannya tentang kuatnya keimanan yang dimiliki, semua itu tidak bisa memberi jaminan. Tetap saja, alat ukur yang paling akurat untuk menilai kemuliaan seseorang adalah kualitas akhlaknya. ${ }^{3}$

Dalam tulisan ini akan diungkap bagaimana inovasi akhlak bisa dibentuk melalui manajemen qolbu yang baik dalam kehidupan.

\section{B. PEMBAHASAN}

\section{Pengertian Inovasi dan Akhlak}

Secara etimologi inovasi berasal dari kata latin innovaation yang berarti pembaharuan dan perubahan. Kata kerjanya innovo yang artinya memperbarui dan mengubah. Inovasi ialah suatu perubahan baru yang menuju ke arah perbaikan dan berencana. ${ }^{4}$

Di dalam kamus besar Bahasa Indonesia, Inovasi di artikan pemasukan satu pengenalan hal-hal yang baru; penemuan baru yang berbeda dari yang sudah ada atau yang sudah dikenal sebelumnya, yang (gagasan, metode atau alat) (tim penyusun kamus pusat pembinaan dan pengembangan bahasa. ${ }^{5}$

Selanjutnya pengertian akhlak secara etimologi adalah berasal dari bahasa arab jamak dari "khuluk" yang artinya perangai. Dalam pengertian sehari-hari akhlak umumnya disamakan artinya dengan budi pekerti, kesusilaan dan sopan santun.

Adapun pengertian akhlak menurut istilah, penulis kutipkan dari berbagai pendapat, yaitu:

Menurut Al-Ghazali akhlak didefinisikan sebagai berikut :

\footnotetext{
2 Zaibari, Manajemen Qalbu (Yogyakarta: Pustaka Pelajar, 2003), 5,6

${ }^{3}$ Abdullah Gymnastiar, Meraih Bening Hati Dengan Manajemen Qolbu, (Gema Insani: 2002), 5.

${ }^{4}$ Idris, Lisma Jamal, Pengantar Pendidikan, (Jakarta :Grasindo,1992). 70.

${ }^{5}$ Kamus Besar Bahasa Indonesia, (Jakarta: Pustaka Pelajar, 2000), 45.
} 


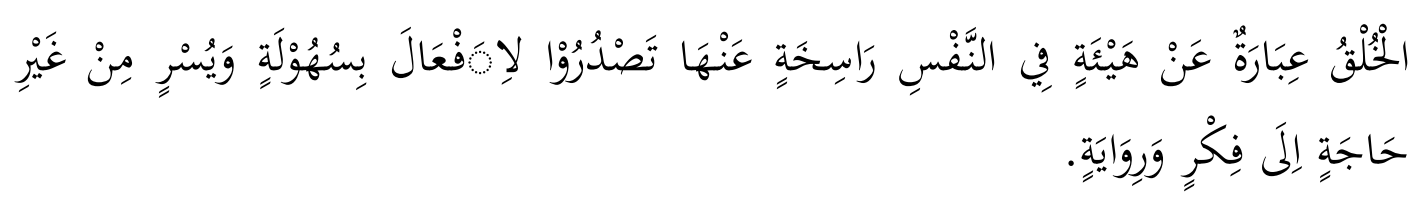

Artinya : "Akhlak adalah ungkapan tentang sikap jiwa yang menimbulkan perbuatanperbuatan dengan mudah dengan tidak memerlukan pertimbangan atau pemikiran terlebih dahulu.

Menurut A. Amin yang dinamakan akhlak adalah : "kehendak yang dibiasakan artinya bahwa kehendak itu bisa membiasakan sesuatu, maka kebebasan itu dinamakan akhlak. Menurut Ibnu Miskawah adalah :

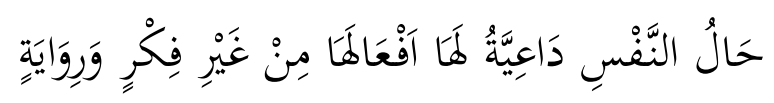

Artinya : "Akhlak adalah sikap jiwa seseorang yang mendorongnya untuk melakukan perbuatan-perbuatan tanpa melalui pertimbangan (terlebih dahulu).

Menurut Barmawaie Umari Akhlak adalah : "Penentuan batas antara baik dan buruk, teruji dan tercela, tentang perkataan atau perbuatan manusia lahir dan batin. Menurut Muhammad bin Ali Asy-Syariif Al-Jurjani.

"Akhlak adalah istilah bagi sesuatu sifat yang tertanam kuat dalam diri, yang darinya terlahir perbuatan-perbuatan dengan mudah dan ringan, tanpa perlu berfikir dan merenung. Jika dari sifat tersebut terlahir perbuatan-perbuatan yang indah menurut akal dan syari'at, dengan mudah, maka sifat tersebut dinamakan dengan akhal yang baik. Sedangkan jika darinya terlahir perbuatan-perbuatan buruk, maka sifat tersebut dinamakan akhlak yang buruk."

Sedangkan kedudukan akhlak adalah universal. Nilai-nilai standar tentang akhlak sudah di hujamkan oleh Allah Swt. Kedalam jiwa manusia sejak mereka lahir. Sebagaimana Firman Allah Swt:

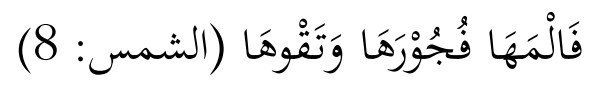

Artinya : Maka Allah mengilhamkan kepada jiwa itu (jalan) kefasikan dan ketaqwaannya (QS. Asy-Syams: 8). ${ }^{6}$

Akhlak dalam Islam tidak semata didasarkan pertimbangan-pertimbangan kemanusiaan. Lebih dari itu akhlak adalah ibadah yang mesti didasarkan atas semangat penghambaan kepada Allah Ta'ala. Seorang muslim menjadikan akhlaknya sebagai sarana mendekatkan diri pada Allah. Dia mengerjakan itu semua bukan didasarkan atas

${ }^{6}$ Al Qur'an dan Terjemahnya (Jakarta, Bumi Aksara, 2000), 88. 
motivasi ingin mencari pamrih, pujian atau kebanggaan. Akhlak adalah rangkaian amal kebajikan yang diharapkan akan mencukupi untuk menjadi bekal ke negeri akhirat nanti. Namun demikian untuk memiliki akhlak yang mulia perlu adanya bimbingan secara khusus.

Salah satunya adalah melalui pendidikan akhlak. Hal inilah yang kemudian dijadikan alasan oleh penulis untuk memfokuskan pembahasan skripsi ini hanya pada pendidikan akhlak. Selanjutnya penulis juga akan membahas tentang qolbu (hati). Karena hati adalah anugerah agung yang Allah karuniakan pada manusia. Dengan hati manusia bisa mengenali, berkomunikasi, bahkan mencintai Rabnya, sekalipun mata dan telinga tiada sanggup meraih wujudnya. Hati adalah juga pusat kebahagiaan. Bahagia atau sengsara bukan tergantung pada seberapa sakinah kondisi hati yang ada dalam dada (Gymnastiar, 2002: 147). Dan hati adalah saksi yang akan menyelamatkan atau mencelakakan. Orang yang kembali kepada Allah dengan hati yang bening berhak mendiami surga yang luasnya-seluas langit dan bumi. Sebagaimana Firman Allah SWT:

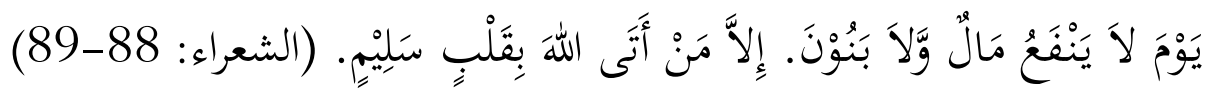

Artinya: (yaitu) di hari harta dan anak-anak laki-laki tidak berguna. Kecuali orangorang yang menghadap Allah dengan hati yang bersih (QS. As-yua'raa': 88-89).

Laksana menara, hati memiliki banyak pintu. Ibarat cermin, hati mampu menyerap dan memantulkan setiap bayangan yang datang kepadanya. Maka pengaruh, obyek, akan masuk kedalam hati, dan membekas didalamnya, melalui sarana lahir, yaitu panca indera, atau lewat sarana batin, yaitu khayalan, syahwat, amarah, akhlak yang terbentuk secara fitrawi. ${ }^{7}$

Bayangkan kalau semua orang kemudian berusaha untuk mendasarkan seluruh aktivitasnya pada hati yang bersih, hati yang tidak ditanami oleh kedengkian, keprihatinan, dan kesombongan. Sungguh akan terjadi ledakan dasyat pada perubahan diri seseorang. Sungguh akan terlihat perubahan yang benar-benar berarti serta penting dan perubahan sesaat. Allah Swt akan lebih memperkaya hati orang-orang seperti ini. Demikian juga dalam dunia pendidikan, alangkah lebih baiknya jika seluruh aktivitas pendidikan didasarkan pada hati yang bersih, khususnya untuk pendidikan akhlak. Karena dengan hati yang bersih akan mampu mencetak generasi muda yang berakhlak mulia, Insya Allah.

${ }^{7}$ Al Ghozali, Relevansinya dengan Pembaharuan Hukum Islam, (Jakarta: Pustaka Firdaus, 2002), 280. 
Nabi Muhammad Saw bersabda, "Mencari ilmu itu wajib hukumnya bagi setiap muslim". Dalam ajaran Islam pengertian adanya keharusan menuntut ilmu hampir senada, "Minat saya mencarinya laksana seorang wanita yang kehilangan anak satusatunya di dunia ini, ia tidak memiliki apapun selain dia". Jadi betapa indahnya menuntut ilmu yang dilandasi dengan kebeningan hati.

Akhirnya, haruslah kita bangun kebeningan hati dalam segala lini kehidupan manusia. Karena telah nampak buah dari keheningan hati itu dalam melejitkan derajat manusia dimata Allah SWT. Bukankah, orang yang mendapat undangan Allah masuk surga kelak ialah hamba-Nya yang memiliki jiwa bening? Allah berseru dalam firmannya:

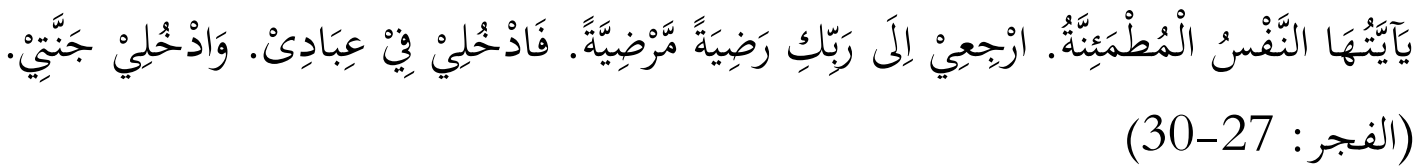

Artinya : "Wahai jiwa yang tenang! Kembalilah kepada tuhanmu dengan ridha (puas), dan diridhai. Maka masuklah dalam (golongan) hamba-hambaku. Dan masuklah dalam surgaku."

Dari uraian diatas dapat disimpulkan bahwa titik sentral perbuatan manusia adalah terletak pada hati. Oleh sebab itu alangkah lebih baiknya jika seluruh aktivitas pendidikan didasarkan pada hati yang bersih, khususnya untuk pendidikan akhlak. Karena dengan hati yang bersih diharapkan akan mampu mencetak generasi muda yang berakhlaq mulia. Dan hal inilah yang kemudian dijadikan oleh penulis untuk memilih manajemen qolbu sebagai dasar/basis dalam pelaksanaan pendidikan akhlak.

\section{Hubungan Akhlak Dengan Manajemen Qolbu}

Akhlak merupakan pondasi yang kokoh bagi terciptanya hubungan baik antara hamba dan Allah SWT (Hablumminallah) dan antar sesama (Hablumminannas). Akhlak yang mulia tidak lahir berdasarkan keturunan atau terjadi secara tiba-tiba, akan tetapi, membutuhkan proses panjang. Yakni melalui pendidikan akhlak. Banyak sistem pendidikan akhlak, moral atau etika yang ditawarkan oleh Barat, namun banyak juga kelemahan dan kekurangannya. Karena memang berasal dari manusia yang ilmu dan pengetahuannya sangat terbatas.

Sementara pendidikan akhlak yang mulia yang ditawarkan oleh Islam tentunya tidak ada kekurangan apalagi kerancuan di dalamnya. Mengapa ? Karena berasal langsung dari Al Khalik Allah SWT, yang disampaikan melalui Rasulullah Muhammad SAW, dengan AI Qur'an dan Sunnah kepada umatnya. Rasulullah SAW sebagai Uswah, Qudwah dan manusia terbaik 
selalu mendapatkan tarbiyah "Pendidikan" langsung dari Allah melalui Malaikat Jibril. Sehingga beliau mampu dan berhasil mencetak para sahabat menjadi sosok-sosok manusia yang memiliki Izzah di hadapan umat lain dan akhlak mulia di hadapan Allah.

Manajemen Qalbu merupakan suatu upaya yang terus menerus untuk melatih menata hati (Qalbu) sehingga Qalbu itu memiliki sifat yang hanif (lurus), dan tentu saja menjadikan niat ibadah sebagai landasan dalam melakukan perbuatan apapun.

Manusia bukanlah roh saja, atau bukan juga sepotong jasmani. Keduanya adalah satu dalam satu manusia. Apakah yang akan jadi akibat jika kita mempunyai satu pikiran dalam hati kita? Pikiran itu tentu akan mempunyai pengaruh pada jasmani manusia. Karena manusia tahu bahwa ia berbuat salah, dan berbuat salah itu berupa sebagai beban dalam hatinya, dengan sendirinya pengertian kesalahan itu akan mempunyai akibat dalam rasa perasaan manusia. la bersalah, salah mempunyai sanksi (tuntutan pembalasan), dari itu timbul rasa takut dalam diri manusia. Rasa takut karena tiap kesalahan batin pada hakikatnya akan mengingatkan kita kepada pencipta hukum alam yang tertanam dalam hati sanubari manusia, dari itu manusia merasa takut karena telah berbuat yang bertentangan dengan kehendak pembuat hukum kodrat manusia.

Peranan yang dibawa oleh hati nurani manusia sebelum perbuatan ialah memberi nasehat bagi manusia. Nasehat itu dapat positif dan dapat pula negatif. Positif akan tampak jika perbuatan itu juga positif bentuknya. Perbuatan adalah positif jika selaras dengan alam kodrat manusia. Dengan sendirinya adalah positif karena selaras, cocok, sejalan, menyerupai dengan bentuk alam kodrat manusia. tentangan tentu akan berwujud tindakan yang negatif, karena tidak akan membawa konstruksi kepada perkembangan alam manusia akan tetapi destruksi, dan destruksi adalah suatu hal yang negatif. Nasehat positif akan berbunyi berbuatlan nasehat negatif akan berbunyi : Janganlah kau berbuat ! Jadi nasehat akan berupa suatu perintah halus atau larangan jangan sampai berbuat (Salam, $2000: 130$ ).

Dari uraian di atas dapat disimpulkan bahwa sesungguhnya akhlak bergantung pada Qalbu. Qalbu yang baik melahirkan akhlak yang baik, Qalbu yang buruk melahirkan akhlak yang buruk. Artinya Qalbu merupakan kunci dari akhlak seseorang dan akhlak ini yang menetukan kemampuan seseorang untuk menyelesaikan setiap masalah yang datang. Qalbu yang hanif (lurus, baik) tidak mungkin tercipta tanpa iman, ilmu dan latihan. Salah satunya adalah dengan Manajemen Qalbu. 


\section{Inovasi Pendidikan Akhlak Berbasis Manajemen Qolbu}

Di dalam Qolbu terhimpun perasaan moral, mengalami dan menghayati tentang salahbenar, baik buruk serta berbagai keputusan yang harus dipertanggung jawabkannya secara sadar, sehingga kualitas Qalbu akan menentukan apakah dirinya bisa tampil sebagai subjek, bahkan sebagai wakil Tuhan di muka bumi, ataukah terpuruk dalam kebinatangan yang hina. Untuk itu perlu upaya untuk membersihkan dan memberikan pencerahan Qolbu, yaitu dengan cara penyucian jiwa (Tazkiyah An Nafs) yang berarti menghiasi diri dengan sifat-sifat terpuji, sesudah membersihkannya dari sifat-sifat tercela. Dengan kata lain diri dibersihkan dari kotoran dan kerusakannya diubah menjadi An Nafs Al Lawwamah (jiwa yang mencela) dan akhirnya menjadi An Nafs Al Muthma'innah. Selanjutnya adalah dengan cara menghapus kecintaan terhadap dunia serta menghilangkan segenap kesedihan, kedukaan dan kekhawatiran atas segala sesuatu yang tidak berguna yaitu dengan cara senantiasa dan terus menerus mengingat Allah (Dzikrullah).

Senantiasa berkemauan kuat untuk meningkatkan kemampuan (keprofesionalan) diri dalam bidang apapun.

Realisasi kunci pertama dilakukan dengan berusaha untuk introspeksi (penilaian) diri dengan tekad untuk memperbaiki diri. Penilaian diri dimulai dari lingkungan yang terkecil seperti keluarga. Setelah lingkungan keluarga, penilaian diri diperluas ke saudara-saudara terdekat dan kemudian orang-orang di sekitar kita. Yakinlah bahwa semakin diri dapat dibuat terbuka, dapat menerima kritikan dengan keikhlasan, Insya Allah perkembangan kemampuan diri akan semakin baik. Untuk pembersihan hati ada lima tahap yang perlu ditempuh, antara lain :

1. Adanya tekad kuat untuk memahami dan memperbaiki diri serta membersihkan hati.

2. Memiliki "ilmu" mengenai pemahaman atau pengenalan diri. Sebab seseorang dapat membersihkan hati melalui perbaikan diri secara kontinu jika telah menyadari keadaan dirinya.

3. Menafakuri diri sendiri melalui evaluasi diri dengan bekal ilmu (tentang pengendalian diri) yang dimilikinya.

4. Proses mengevaluasi diri perlu untuk diperluas. Dengan kata lain, evaluasi diri dibicarakan secara terbuka dan bersama-sama sehingga proses pembersihan Qalbu semakin efektif.

5. Berkaitan dengan proses pembelajaran yaitu bagaimana diri mau belajar dari diri orang lain. 
Sedangkan untuk kunci yang kedua diperlukan adanya kejujuran sebagai modal dasar untuk membentuk jiwa yang tangguh, penuh dedikasi dan disiplin dalam menjalankan kerja sehari-hari. Manajemen Qalbu tidak hanya membentuk manusia yang ahli dzikir dan ahli fikir tetapi juga manusia yang ahli ikhtiar. Hal ini akan berkaitan dengan amal nyata dan karya nyata melalui proses pelatihan bidang untuk peningkatan kualitas keprofesionalan.

Adapun bentuk pelaksanaan Manajemen Qolbu yang bersifat kelompok, dilaksanakan dengan sistem ta'lim yang dibagi ke dalam beberapa kelompok lain. Materi yang diberikan bertendensi kepada pembentukan akhlak seperti ; kesabaran, kejujuran, keteladanan. Ayatayat dan hadits-hadits pendukung juga disiapkan dalam materi tersebut. Ada tiga materi pokok yang terkait dengan Manajemen Qolbu yaitu keutamaan hati, mengenal potensi manusia dan potensi diri sendiri serta pengenalan diri.

\section{E. KESIMPULAN}

Dari pemaparan diatas maka dapat disimpulkan bahwa Inovasi Pendidikan Akhlak Berbasis Manajemen Qolbu adalah suatu ide atau metode baru yang ditawarkan oleh penulis untuk digunakan di dalam melaksanakan pendidikan akhlak. Dan diharapkan ide atau metode yang baru ini dapat meningkatkan mutu pendidikan akhlak yang dirasakan semakin menurun dewasa ini. Adapun cara melakukan inovasi pendidikan akhlak berbasis manajemen qolbu adalah senantiasa menghiasi diri dari sifat-sifat terpuji, sesudah membersihkannya dari sifat-sifat tercela, menghapus kecintaan terhadap dunia serta menghilangkan segenap kesedihan, kedukaan dan kekhawatiran atas segala sesuatu yang tidak berguna dengan cara senantiasa dan terus menerus mengingat Allah (Dzikrullah), kemudian adanya tekad yang kuat, mau mengevaluasi diri dan senantiasa berkemauan kuat untuk meningkatkan kemampuan (keprofesionalan) diri dalam bidang apapun. 


\section{DAFTAR PUSTAKA}

As-Sakandary, Ahmad bin Atha'illah, 2005, Menggapai Tingkatan Shufi dan Waliyullah (Terjemah Syarah Al-Hikam), Alih Bahasa Musa Turoicham AlQudsiy,Surabaya,Ampel Mulia. . 2005. Menggapai Tingkatan Shufi dan Waliyullah (Terjemah Syarah AlHikam). Alih Bahasa Musa Turoichan Al-Qudsy. Surabaya: Ampel Mulia.

Al Ghazali, 2008, Membangkitkan Energi Qalbu, Mitrapress, 2008. ,Rahasia Keajaiban Hati,Disadur Immun El Blitary,Surabaya,Al Ikhlas.

,Ringkasan Ihya' Ulumuddin, 2007, Alih bahasa Zeid Husein Al-Hamid, Jakarta, Pustaka Amani.

. 2007. Mukhtashar Ihya' Ulumuddin. Dialihbahasakan Zeid Husen Al Hamid. Jakarta: Pustaka Amani. . 2008. Membangkitkan Energi Qalbu. Mitrapress. . Rahasia Keajaiban Hati. Disadur Immun El Blitary. Surabaya: Al Ikhlas.

Gymnastiar, A. 2003. Refleksi Manajemen Qalbu. Bandung: MQ Publishing. 